\title{
DAUGIAKANALIO CIKLONO PANAUDOJIMO DUJŲ SRAUTO DULKĖTUMUI MAŽINTI AGRESYVIOJE APLINKOJE TEORINIS VERTINIMAS
}

\author{
Aleksandras CHLEBNIKOVAS ${ }^{1}$, Pranas BALTRÉNAS ${ }^{2}$ \\ Vilniaus Gedimino technikos universitetas, Vilnius, Lietuva \\ El.paštas. ${ }^{1}$ aleksandras.chlebnikovas@vgtu.lt; ${ }^{2}$ pbalt@vgtu.lt
}

\begin{abstract}
Santrauka. Naujos kartos daugiakanaliais ciklonais smulkiadispersès kietosios dalelès pašalinamos iš užterštų dujų. Naudojant šiuos įrenginius, yra atskiriamos ir nusodinamos kietosios dalelès, kurių minimalus skersmuo siekia 2 mikrometrus, taip gaunama iki $95 \%$ valymo efektyvumo. Tokios konstrukcijos ciklonai dažniausiai yra naudojami ịprastomis sąlygomis, esant padidintai temperatūrai ir nedideliam drégniui. Esant agresyvioms aplinkos sąlygoms, šie ịrenginiai užsikemša, o jų regeneruoti negalima. Tolesniuose ciklono veikimo parametrų tyrimuose numatoma analizuoti, kaip, taikant konstruktyvius sprendimus, pritaikyti cikloną ir šalinti kietąsias daleles iš dujų esant agresyvioms aplinkos sąlygoms. Šioje teorinėje analizèje yra aprašomas dujų srauto charakteristikų bei kietąsias daleles veikiančių jègų pokytis esant skirtingai agresyviai aplinkai. Tokios sąlygos buvo apibrèžtos, nustačius $50-200{ }^{\circ} \mathrm{C}$ dujų srauto temperatūros intervalą ir tiriant dujų-garų srautą, kurio drègnis siekè 70-100\%. Ivertinta agresyvių aplinkos sąlygų įtaka, daroma dujų srauto dinamikos jègoms - slègio, pasipriešinimo ir išcentrinei. - ir kietụjų dalelių mechaninèms jègoms - gravitacijos ir adhezijos. Visi vertinami parametrai palyginti su vertėmis normaliomis sąlygomis.
\end{abstract}

Reikšminiai žodžiai: daugiakanalis ciklonas, agresyvios aplinkos sąlygos, kietosios dalelès.

\section{Ivadas}

Imta plačiai taikyti oro valymo įrenginius, kuriuose kietosios dalelès (toliau KD) nusodinamos veikiant išcentrinėms jègoms. Vieni populiaresnių yra ciklonai. Nors jie naudojami jau seniai, iki šiol nėra visiškai ištirti, o veikimo principas nėra išsamiai apibrèžtas. Ciklone vykstantys reiškiniai yra sudėtingi, o papildomi konstrukciniai sprendimai dar labiau apsunkina tyrimus. Ciklone veikia tiek išcentrinès, tiek gravitacinès jègos, esant sudètingam sūkuriniam judèjimui (Altmeyer et al. 2004). Ciklonai dažniausiai parenkami pagal empirinius duomenis, todèl pramoneje naudojami ịvairių konstrukcijų ciklonai (Hoffmann, Stein 2002; Hu et al. 2005; Raoufi et al. 2008).

Skirtingos rūšies dulkètam srautui sausai valyti esant iprastoms sąlygoms seniai naudojami tradiciniai ciklonai, tačiau jie nèra itin efektyvūs valant dujas, ypač užterštas mažo dispersiškumo (iki $20 \mu \mathrm{m}$ skersmens) teršalų KD (Wang et al. 2006). Jie veikia pagal dažną ciklono kietụjų dalelių atskyrimo principą (ciklonai CN, CKTI, C, NIIOGaz), valymo efektyvumas siekia 75-85\%, o iš oro pašalinamos KD, kurių skersmuo yra didesnis nei 20 mikronų (Kaya, Karagoz 2008). To nepakanka, siekiant igyvendinti Direktyvos tikslus dèl aplinkos oro kokybès ir švaresnio oro Europoje (Direktyva 2008/50/EB) ir atitikti
Direktyvos dèl kietujų dalelių ribines vertes aplinkos ore (Tarybos direktyva 1999/30/EB), atsižvelgiant ị reglamentuojamų $\mathrm{KD}_{10}$ ir $\mathrm{KD}_{2,5}$ (kietosios dalelès, kurių skersmuo iki $10 \mu \mathrm{m}$ ir 2,5 $\mu \mathrm{m}$ atitinkamai) teršalų frakcijų išmetamąsias koncentracijas.

Daugiakanaliai ciklonai plačiai naudojami neagresyviomis aplinkos sąlygomis smulkiadispersèms nuo $1 \mu \mathrm{m}$ dydžio KD sugaudyti (Avci, Karagoz 2003). Juose iš užteršto dulkèto srauto, kuris pereina pro ciklono kanalų sistemą, išvalomos teršalų dalelès ne tik veikiant išcentrinėms jègoms, bet ir papildomai sulaikant dalị KD susidariusiomis „dujų srauto užuolaidomis“ ir nukreipiant teršalus i segmentinius plyšius separavimo kameroje (Baltrènas et al. 2012; Burov et al. 2007; Vaitiekūnas, Jakštonienè 2010).

Tradiciniai ir daugiakanaliai ciklonai yra labiau pritaikyti valyti lipniąsias KD iš dujų srauto, tačiau esant ypatingoms sąlygoms - aukštam drègniui, padidintai temperatūrai ir veikiant tam tikriems dujų srauto cheminiams junginiams - ciklonai užsikemša ir valymo procesas sustoja. Jų atkurti praktiškai neįmanoma. Todèl reikia papildomai moksliškai įvertinti valymo ịrenginių eksploatavimą tokiomis sąlygomis ir įdiegti konstrukcinius patobulinimus.

Plačiausiai naudojamuose tradiciniuose bei daugiakanaliuose ciklonuose KD valymo iš dujų tolydumą lemia 
kietujų dalelių sąveika su ribojančiais srautus paviršiais. Taip pat daro ittaką besiformuojantys KD nuosėdų sluoksniai ant paviršių, kurie pakeičia srautų judejjimą ir neigiamai veikia dalelių nusėdimo mechanizmą, todèl KD sugaudymo efektyvumas mažèja (Bernardo et al. 2006; Yoshida et al. 2005; Mothes, Loffler 1988; Sobolev et al. 2011).

Drègno dujų srauto judèjimo metu ciklono kanaluose formuojasi KD nuosėdų sluoksniai. Šiuo atveju analizuojamas tamprus teršalų dalelių atšokimas ir adhezija su paviršiumi, šių dviejų veiksnių jẻgų dydžiai, šios jègos palyginamos tarpusavyje. Šių jėgų santykis yra tiesiogiai proporcingas dalelių skersmens trečiajam laipsniui. Taigi smulkiosioms dalelèms sąveikaujant su paviršiumi reikšmingos yra adhezijos ir autohezijos jègos. Tyrimais yra nustatyta, kad net stačiakampiame kanale KD intensyviai nusėda ant paviršiaus. Mažosiomis dalelèmis yra laikomos tokios, kurios yra nešamos kartu su srautu dèl turbulentinių fliuktuacijų (Sobolev et al. 2011; Winfield et al. 2013).

Pirmajame KD nuosėdų formavimosi etape iš smulkių dalelių susidaro monosluoksniai, išlyginantys paviršių. Ant jų pradeda tekèti laminarinio pobūdžio dujų srautas, pasižymintis nedideliu disperguojančiu poveikiu nuosėdoms. Nuosėdoms kaupiantis ị ši sluoksni jị sutankindamos gali ìsiterpti stambesnès dalelès (Sobolev et al. 2011).

I ciklono separavimo kamerą įtekant užterštam dujų srautui, smulkiujuc dalelių aglomeratai konstrukcijos išlinkimuose patenka ant sienelių ir prilimpa prie jų. Šiuo atveju, priklausomai nuo šių aglomeratų masės ir jų koordinačių išdèstymo ciklono ịtekèjimo skerspjūvyje, prilipimas bus netolygus, ir ant paviršiaus susidarys nelygumai.

Yra žinoma, kad valymo įrenginio matmenims didèjant, mažèja jo valymo efektyvumas, tačiau didelių matmenų ciklonai pasižymi galimybe nusodinti ir smulkiąsias daleles, nes arti paviršių veikia papildomos inercijos jègos, atsirandančios dalelių turbulentinès pernašos metu, esant dideliems dalelių pulsacinių greičių gradientams, nukreiptiems link paviršiaus (Gordon, Peisahov 1977). Dideliuose ciklonuose dèl mažesnių išcentrinių pagreičių arti ribojančių srautus paviršių aglomeratų, kuriuos sudaro smulkiosios dalelès, prilipimas yra mažiau tikètinas (Gong, Wang 2004; Sobolev et al. 2011).

Plečiantis gamybos ir technologijų įvairovei, atsiranda naujų procesų, kuriems vykstant susidaro ypatingos aplinkos sąlygos. Tokių procesų metu agresyvios aplinkos sąlygos sudaro kliūčių įrenginiams atlikti valymo funkcijas. Šiuolaikiniai valymo ịrenginiai nèra tinkami eksploatuoti tokiomis sąlygomis. Šioms problemoms spręsti reikia specialių įrenginių (Luca, Ioan 2012; Pushnov, Berengarten 2011).

KD ir dujų savybès gali keistis, kai kietosios dalelès išsiskiria. Labai sudètinga ịvertinti kietujų dalelių sugaudymo efektyvumą ciklonuose dèl ịvairių tam ịtaką darančių veiksnių gausos, todèl būtina sumažinti įtaką darančių veiksnių skaičių darant tam tikras prielaidas (Gujun et al. 2008; Zhao et al. 2006).

Tyrimų tikslas - teoriškai įvertinti daugiakanalio ciklono darbo parametrų kitimą esant agresyvioms aplinkos sąlygoms, remiantis charakteristikų sąryšiais (teorinėmis matematinėmis išraiškomis), tokiu būdu nustatyti ir palyginti dujų srauto aerodinaminių parametrų bei KD veikiančių jègų ir atskyrimo efektyvumo pokyčius esant agresyvioms aplinkos sąlygoms, kai dujų srauto drėgnis kito nuo 0 iki $100 \%$, temperatūra nuo 0 iki $200{ }^{\circ} \mathrm{C}$.

\section{Metodika}

Tiriamas naujos kartos oro valymo įrenginio eksperimentinis stendas įrengtas Vilniaus Gedimino technikos universiteto (VGTU) Aplinkos apsaugos institute. Daugiakanalio ciklono principinès schemos pavaizduotos 1 pav.

Dvifazis oro srautas tangentiškai įteka pro įejimo angą ir patenka i separavimo kamerą, ì pirmajị ciklono kanalą, kuris yra ribojamas periferinès sienelès bei pirmojo kreivinio ketvirtžiedžio. Srautas, ištekèdamas iš ankstesniojo kanalo, susidūręs su pusžiedžio (ketvirtžiedžio) sienele (briauna), pasidalija i du srautus - periferini ir tranzitinį. Periferinio srauto dalis patenka iz ankstesnic kanalą, taip vyksta užteršto srauto filtracija grịžtamuoju srautu, o tranzitinis srautas - i paskesnị kanalą link ịrenginio ašies, kad ištekètų iš ciklono. Tokiu būdu tekèdamas oro srautas pasiskirsto skirtingo kreivumo kanaluose bei filtruojasi per tarpus, esančius tarp ketvirtžiedžių.

Veikiant išcentrinėms jègoms, kurias sukuria sūkurinis srautas, ir filtracijos efekto, atsiradusio srautų persiskyrimo zonoje, KD yra nusodinamos bei kaupiamos ciklono bunkeryje, patekdamos i ji pro segmentinius žiedinius plyšius.

Išvalytas oras, perèjęs pro visus ciklono kanalus, išteka iš sistemos per oro srauto išejjimo angą. Dulkètas oras yra filtruojamas kanalų tarpų aktyviojoje zonoje bei valosi koaguliuojant KD.

Drégmés įtaka duju srauto parametrams. Drègme yra vadinamas vandens garų kiekis, esantis dujinèje fazèje.

Tokio vandens garų dujų srauto dalinis slègis nėra didesnis už įsotintų garų slègị esant tam tikroms dujų srauto sąlygoms. Dujų sraute atsirandantys vandens garai sumažina dujų tankị, nes vandens molinè masè yra mažesnè (18 g/mol), lyginant su sauso dujų srauto moline mase (29 g/mol). Drègnas dujų-garų srautas gali būti laikomas idealiujų dujų mišiniu, kurio kiekvieno iš komponentų tankis yra atitinkamas, kad būtų pasiektas reikiamas mišinio tankis. Taip yra ịmanoma nustatyti tankio vertę, esant 


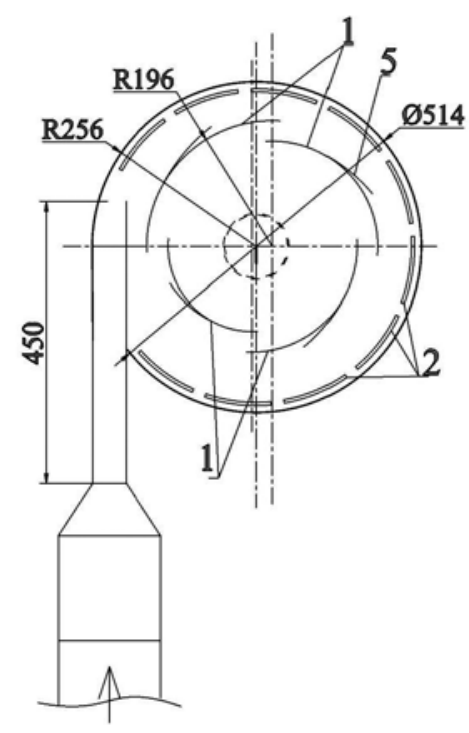

a

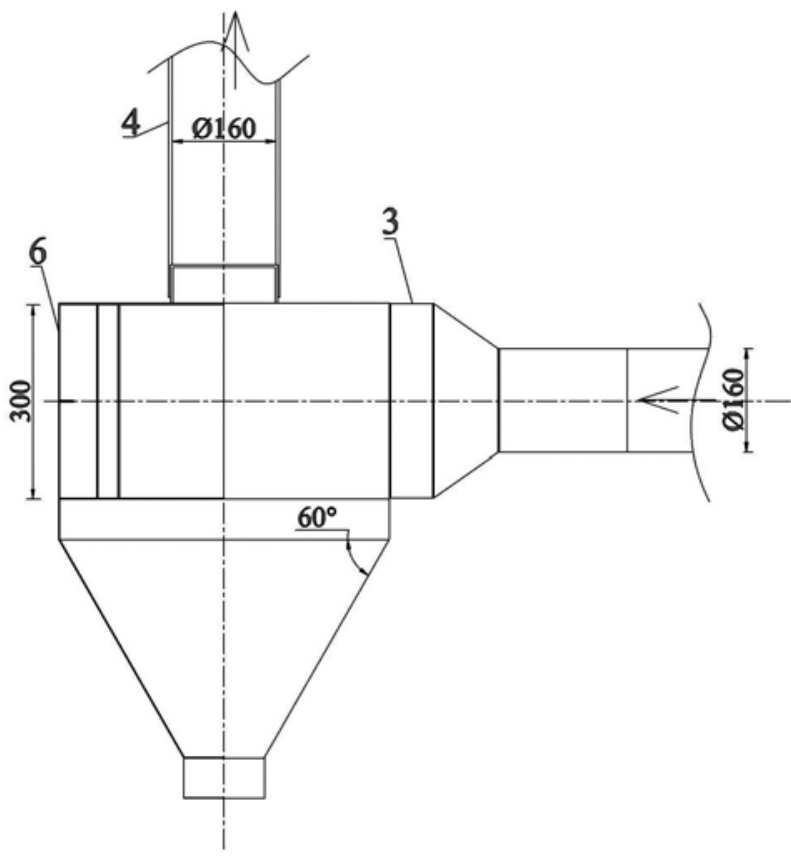

b

1 pav. Daugiakanalio ciklono vaizdas iš viršaus (a) ir profilis (b): 1 - kreiviniai ketvirtžiedžiai su angu plokštelių atlenkimais, 2 - segmentiniai žiediniai plyšiai, 3 - įtekejjimo anga, 4 - išvalyto srauto ištekejjimo ortakis, 5 - ketvirtžiedžių atlenktos plokštelès, 6 - ciklono separavimo kamera

Fig. 1. Multi-channel topview (a) ir sideview (b): 1 - curvilinear quarter-rings with folded opening slots, 2 - segment circular spacings, 3 - inlet opening, 4 - cleaned airflow outlet, 5 - folded opening slots of quarter-rings, 6 - cyclone separation chamber

mažiau nei $0,2 \%$ paklaidai, kai temperatūra kinta nuo -10 iki $+50{ }^{\circ} \mathrm{C}$. Buvo teoriškai ịvertinti atvejai, kai temperatūra kito nuo 0 iki $200{ }^{\circ} \mathrm{C}$, o drègnis atitinkamai nuo 0 iki 70 \%. Laikoma, kad dujų srauto temperatūra atvirkščiai proporcinga jo drègniui. Drègno dujų srauto tankio sąryšis su agresyvios aplinkos sąlygų parametrais aprašomas tokia formule:

$$
\rho_{\text {d.d.s. }}=\frac{p_{s . d .}}{R_{\text {s.d. }} \cdot T}+\frac{p_{v . g .}}{R_{v . g .} \cdot T},
$$

čia $\rho_{\text {d.d.s. }}$ - drègno dujų srauto tankis, $\mathrm{kg} / \mathrm{m}^{3} ; p_{\text {s.d. }}$ - sauso dujų srauto dalinis slègis, $\mathrm{Pa} ; R_{\text {s.d. }}$ - sauso dujų srauto pastovioji, kuri lygi 287,058, J/(kg·K); $T$ - temperatūra, $\mathrm{K} ; p_{v . g .}$ - vandens garų slègis, $\mathrm{Pa} ; R_{v . g .}-$ vandens garų pastovioji, kuri lygi 461,495, $\mathrm{J} /(\mathrm{kg} \cdot \mathrm{K})$.

Vandens garų slègis taip pat gali būti apskaičiuotas pagal santykinị drègnị:

$$
p_{v . g .}=\varphi \cdot p_{\text {is.g. }},
$$

čia $p_{v}$ - vandens garų slègis; $\phi-$ santykinis drègnis; $p_{\text {is.g. }}-$ issotintų garų dalinis slègis, kuris gali būti apskaičiuotas pagal formulę:

$$
\rho_{\text {is.g. }}=6.1078 \cdot e^{\frac{17,08085 \cdot t}{234,175+t}},
$$

čia: $p_{i s . g .}$ - vandens garų slègis, $\mathrm{kPa}, t$ - vandens garų tem- peratūra, ${ }^{\circ} \mathrm{C}$.

Keičiantis aplinkai, pasikeičia ir veikiančios dalelę jègos judančiame dujų sraute.

Dujų ir dalelių srautui judant ciklono kanalais atsiranda daleles veikianti slègio jèga (pasipriešinimo jèga), kuriai veikiant dalelè juda horizontaliame sraute.

Slègio jègą i dalelę dujų sraute galima apskaičiuoti pagal formulę:

$$
F_{s l .}=c S \rho \frac{\bar{u}^{2}}{2},
$$

čia $c$-dalelès pasipriešinimo koeficientas; $\rho$-dujų srauto tankis, $\mathrm{kg} / \mathrm{m}^{3} ; S$ - judančios dalelès skerspjūvio plotas, $\mathrm{m}^{2}$; $\bar{u}$ - vidutinis dujų srauto greitis, $\mathrm{m} / \mathrm{s}$.

Slègio jègos pokytis dèl agresyvios aplinkos sąlygu parametrų buvo vertinamas analogiškais atvejais, kaip ir dujų srauto tankis.

Dujų srauto sudaromos jëgos veikimo ị dalelę dydis yra proporcingas dujų srauto greičio antrajam laipsniui, t. y. $F \sim \bar{U}^{2}$, todèl, mažejjant dujų srauto greičiui ciklone, jèga sumažèja kvadratu. Dèl šios priežasties dalelių nutraukimas nuo paviršiaus tolstant nuo ciklono įtekejjimo angos reikšmingai mažeja ir esant 10-15 mm atstumui praktiškai išnyksta.

Matyti dalelę veikianti išcentrinė jèga, kuri veikia būdingą dalelę jai judant ciklono kanale aplink ịrenginio 
ašị. Šios jègos dydis priklauso nuo judančios dalelès inercijos, nes jos judejjimo kryptis daugiakanaliame ciklone nuolat keičiasi. Šios jègos dydis yra apskaičiuojamas pagal formulę:

$$
F_{c}=\frac{\frac{4}{3} \pi \rho_{d} r_{d}^{3} V_{t}^{2}}{r},
$$

čia $\rho_{d}$ - dalelès tankis, $\mathrm{kg} / \mathrm{m}^{3} ; r_{d}$ - dalelès spindulys, $\mathrm{m}$; $V_{t}$ - dujų srauto greitis, $\mathrm{m} / \mathrm{s} ; r$ - ciklono kanalo spindulys, m.

Dujų srautas, judantis daugiakanaliame ciklone, yra turbulentinio pobūdžio, todèl pasipriešinimo jẻgos lygtis yra:

$$
F_{p}=0,173 d^{2}(u-v)^{2} \rho,
$$

čia $\mu$ - dinaminès klampos koeficientas; $u$ - dujų srauto greitis ciklone, $\mathrm{m} / \mathrm{s} ; v$-dalelès greitis ciklone, $\mathrm{m} / \mathrm{s}$.

Panaudodami dinaminès ir kinematinès klampos koeficientų sąryšị $\mu=v \rho$, pasipriešinimo jègos lygtị turbulentiniam dujų srauto tekẻjimui galime užrašyti taip:

$$
F_{p}=0,173 d(u-v) \operatorname{Re} \mu .
$$

Dalelei judant ciklono kanalu, ją veikia ne tik dujų srauto išcentrinès jègos, bet ir pačios turinčios masę dalelès gravitacijos jègos. Ši jèga pakeičia daleliu judèjimo trajektoriją, dèl to jos gali būti išskirtos iš dujų srauto ir nusodintos ciklono bunkeryje. Vertinant buvo taikoma standartinè nagrinejjamą kūną veikiančios svorio jègos išraiška:

$$
F_{g r .}=4 \frac{\pi\left(\frac{d}{2}\right)^{3}}{3} \cdot \rho_{d} \cdot g .
$$

Laikoma, kad dalelès tankis yra lygus $1000 \mathrm{~kg} / \mathrm{m}^{3}$, dalelè yra sferinè. Buvo vertinta 1, 2,5, 5, 10 ir $20 \mu \mathrm{m}$ dydžio daleles veikianti gravitacijos jèga.

Adhezijos reiškiniai atsiranda dalelei tiesiogiai susilietus su paviršiumi ir yra jų molekulinio tarpusavio veikimo rezultatas. Adhezijos jèga priklauso nuo kontakto paviršiaus ploto, nes molekulinè sąveika proporcinga kontakto plotui.

Smulkiadispersiu prikibusių KD atitraukimas nuo paviršiaus veikiant dujų srautui vyksta keliais etapais. Iš pradžiu yra atitraukiamos viršutinès stambesnès dalelès, o vèliau smulkesnès, kai jas ịveikia sluoksnio adhezijos jèga. Viršutinių dalelių nutraukimas galimas, kai $F_{\text {adh }}>F_{\text {autoh }}$. Dalelių nutraukimas veikiant autohezijos jẻgoms vadinamas erozija. Kai $F_{\text {adh }}<F_{\text {autoh }}$, sluoksnis nutraukiamas nuo pat paviršiaus. Šiuo atveju yra nugalimos adhezijos jègos, šis procesas vadinamas denudacija.

Darant prielaidą, kad elektrinių ir kapiliarinių jègų, tikrosios dalelių formos ir kitu veiksnių nepaisoma, adhezijos jèga yra išreiškiama priklausomybe:

$$
F_{\text {adh. }}=\frac{h \omega}{16 \pi z_{0}^{2}} d=\frac{h \omega}{8 \pi z_{0}^{2}} r,
$$

čia $h \omega$ - Livšico ir Planko konstanta, J; $z_{0}$ - tarpas tarp dalelès ir plokštumos paviršiaus, kuriam esant adhezijos jègos yra didžiausios; $r$ - dalelès spindulys, $m$.

Atlikus tyrimus nustatyta, kad, esant tarpui $4 \cdot 10^{-10} \mathrm{~m}$, adhezijos jèga maksimali ir yra lygi:

$$
F_{a d h .}=2,4 \cdot 10^{-7} r \text {. }
$$

Adhezijos jëgos mažèja proporcingai tarpo tarp paviršių kvadratui. Todèl smulkiosios dalelès turi didesnị tarpo tarp paviršių plotą, lyginant su stambiomis dalelèmis, ir jų adhezijos jèga yra didesnè negu stambiujų dalelių. Dèl šios priežasties stambiosioms dalelėms nutraukti nuo paviršiaus reikalinga mažesnè jèga, nei nutraukiant smulkiadisperses daleles. Taigi stambesnès dalelès yra nutraukiamos nuo paviršiaus lengviau ir esant mažesniems dujų srauto greičiams.

Adhezijos jègos buvo iqvertintos 1, 2,5, 5, 10 ir $20 \mu \mathrm{m}$ dydžio dalelèms, darant prielaidą, kad visais atvejais adhezijos jèga yra maksimali.

\section{Rezultatai ir jų analizè}

Agresyvios aplinkos sąlygos neigiamai veikia daugiakanalio ciklono darbą, pasikeičia ciklono aerodinaminiai, fiziniai ir valymo efektyvumo parametrai. Esant šiems pokyčiams, dujų srautas ịsotinamas drègme bei padideja KD sulipimas, atsiranda adhezijos jègų, veikiančių vidinius ciklono elementus, ir autohezijos jègų, veikiančių KD tarpusavyje, pokyčių. Dèl šių veiksnių susidaro dujų ir garų aplinka, daugiakanalio ciklono sistema užsikemša, įrenginys toliau negali būti eksploatuojamas.

Norint nustatyti drẻgnio ir temperatūros ịtaką dujų srauto tankiui, pagal (1), (2) ir (3) formules yra apskaičiuojami skirtingi agresyvios aplinkos atvejai, kintant būdingiesiems parametrams. Rezultatai pateikti 2 pav. ir 1 lentelëje.

Esant padidintai dujų temperatūrai $\left(50^{\circ} \mathrm{C}\right)$ ir drègniui $95 \%$, sausų dujų srauto tankis sumažèja apytiksliai 1,18 karto, o drègno dujų srauto - 1,1. Esant tokiai aplinkai, rasos taškas yra pasiekiamas esant $49^{\circ} \mathrm{C}$, todèl galima teigti, kad dujų srautas yra prisotintas vandens garų, o auštant srautui ant šaltesnių paviršių vyksta intensyvi kondensacija.

Išsildant srautą iki $100{ }^{\circ} \mathrm{C}$ ir $150{ }^{\circ} \mathrm{C}$, galima matyti skirtingą tendenciją tarp drègno ir sauso dujų srauto tankių. Sauso dujų srauto tankio vertès proporcingai mažèja kylant temperatūrai ir esant $150{ }^{\circ} \mathrm{C}$ vertei, skirtumas lyginant su normalioms sąlygomis yra 35,6 \%. Tačiau drègno dujų srauto tankis esant $100{ }^{\circ} \mathrm{C}$ ir $150{ }^{\circ} \mathrm{C}$ temperatūrai yra atitinkamai didesnis 1,17 ir 2,18 karto. 
1 lentelè. Dujų srauto parametrai priklausomai nuo agresyvios aplinkos charakteristiku

Table 1. The gas flow parameters depending on the aggressive environment characteristics

\begin{tabular}{|l|c|c|c|}
\hline \multicolumn{1}{|c|}{ Dimensija } & $\mu_{\text {d.s. }}$ & $v_{\text {d.d.s. }}$ & Rasos taškas \\
\cline { 2 - 4 } & $\mu \mathrm{Pa} * \mathrm{~s}$ & $\mathrm{~mm}^{2} / \mathrm{s}$ & ${ }^{\circ} \mathrm{C}$ \\
\hline $\begin{array}{l}\text { Esant normalioms } \\
\text { sąlygoms }\end{array}$ & 17,17 & 13,28 & - \\
\hline $\begin{array}{l}t=50^{\circ} \mathrm{C}, \\
\phi=95 \%\end{array}$ & 19,26 & 16,44 & 49,0 \\
\hline $\begin{array}{l}t=100{ }^{\circ} \mathrm{C}, \\
\phi=95 \%\end{array}$ & 21,25 & 14,11 & 98,6 \\
\hline $\begin{array}{l}t=150{ }^{\circ} \mathrm{C}, \\
\phi=80 \%\end{array}$ & 23,16 & 8,25 & 142,0 \\
\hline $\begin{array}{l}t=200{ }^{\circ} \mathrm{C}, \\
\phi=70 \%\end{array}$ & 24,99 & 4,26 & 184,0 \\
\hline
\end{tabular}

Kinematinès klampos koeficiento vertè iš pateiktu 1 lentelejje rezultatų yra apskaičiuota esant $50{ }^{\circ} \mathrm{C}$ temperatūrai. Esant temperatūrai aukštesnei kaip $100{ }^{\circ} \mathrm{C}$, šio parametro vertès pradeda mažèti ir yra mažesnès 1,17 ir 1,99 karto esant atitinkamai $100^{\circ} \mathrm{C}$ ir $150^{\circ} \mathrm{C}$ temperatūrai, lyginant su maksimalia verte.

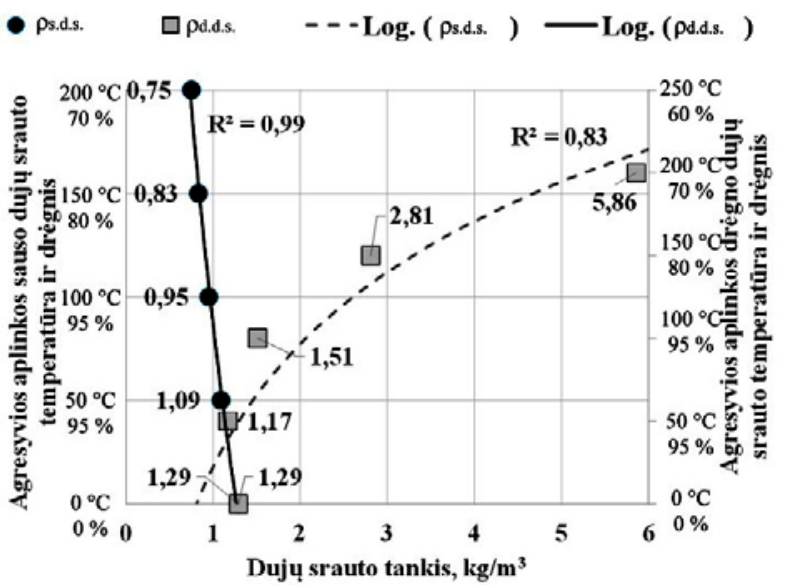

2 pav. Sauso $\left(\rho_{\text {s.d.s. }}\right)$ ir drègno $\left(\rho_{\text {d.d.s. }}\right)$ dujų srauto tankio priklausomybè nuo agresyvios aplinkos temperatūros ir drègnio

Fig. 2. Dependence of dry $\left(\rho_{\text {s.d.s. }}\right)$ and wet $\left(\rho_{\text {d.d.s. }}\right)$ gas flow density on the aggressive environmental temperature and humidity

Atlikus skaičiavimus esant parinktai didžiausiai dujų srauto temperatūrai, kuri lygi $200{ }^{\circ} \mathrm{C}$, ir drègniui $70 \%$, gautas 1,72 karto mažesnis sauso dujų srauto tankis ir 4,54 karto didesnis drègno dujų srauto tankis lyginant su normalioms sąlygomis. Dinaminès ir kinematinès klampos koeficientas atitinkamai yra 1,46 karto didesnis ir 3,12 karto mažesnis lyginant su vertėmis, gautomis esant normalioms sąlygomis.

Dulkètam dujų srautui judant ciklono kanalais, jame esančias daleles veikia srautas, sudarytas išcentrinio ventiliatoriaus pratekant numatytam srauto debitui. Apskaičiavus slègio jëgos pokytị esant $12 \mathrm{~m} / \mathrm{s}$ vidutiniam greičiui ciklone skirtingomis agresyviomis sąlygomis, rezultatai pateikti 2 lentelejje.

Esant normalioms sąlygoms slègio jèga yra lygi $1,07 \mathrm{mN}$. Atlikus fizikinių dujų srauto parametrų pakeitimus dèl temperatūros ir drègnio, nustatyta, kad ịkaitusio iki $50{ }^{\circ} \mathrm{C}$ ir $95 \%$ drègnio srauto veikianti dalelę jèga sumažèja $4,7 \%$.

2 lentelè. Slègio jègos ị dalelę kitimas esant agresyvios aplinkos pokyčiams

Table 2. Alteration of pressure forces into the particle in case of changes in aggressive environment

\begin{tabular}{|l|c|}
\hline \multicolumn{1}{|c|}{$\begin{array}{c}\text { Dujų srauto charakteristika (temperatūra, } \\
\text { drègnis) }\end{array}$} & $\begin{array}{c}\text { Slègio jëga, } \\
\mathrm{mN}\end{array}$ \\
\hline Esant normalioms sąlygoms & 1,07 \\
\hline $\begin{array}{l}t=50^{\circ} \mathrm{C}, \\
\phi=95 \%\end{array}$ & 1,02 \\
\hline $\begin{array}{l}t=100^{\circ} \mathrm{C}, \\
\phi=95 \%\end{array}$ & 1,16 \\
\hline $\begin{array}{l}t=150{ }^{\circ} \mathrm{C}, \\
\phi=80 \%\end{array}$ & 1,58 \\
\hline $\begin{array}{l}t=200{ }^{\circ} \mathrm{C}, \\
\phi=70 \%\end{array}$ & 2,37 \\
\hline
\end{tabular}

Kaip galima matyti 2 lentelëje, aukštesnès nei $50{ }^{\circ} \mathrm{C}$ temperatūros dujų srautas veikia dalelę didesne jèga, kuri itin didèja iki pat $200{ }^{\circ} \mathrm{C}$. Didžiausias pokytis pastebètas esant $150{ }^{\circ} \mathrm{C}$ ir $200{ }^{\circ} \mathrm{C}$ temperatūrai, kai slègio jèga atitinkamai padideja 1,48 ir 2,21 karto, lyginant su normaliomis sąlygoms. Galima daryti prielaidą, kad akivaizdus slègio jègos didejjimas įvyksta dèl drègno dujų srauto tankio padidejjimo esant aukštai temperatūrai. Slègio jèga yra tiesiog proporcinga greičio kvadratui, tačiau pastarojo pokytis nèra toks reikšmingas kaip dujų srauto tankis. Galima teigti, kad esant agresyviai aplinkai dalelè bus lengviau nešama dujų srauto, tai gali turèti ịtakos papildomam dalelių išnešimui iš ciklono. Iš kitos pusès, tokiai aplinkai esant dujų srauto veikiama dalelè gali būti lengviau nukreipta ị segmentinius plyšius ir nusodinta ciklono bunkeryje, o tai padidintų valymo efektyvumą.

Esant aplinkos sąlygų pokyčiui nuo normaliujų pagal (5) formulę yra apskaičiuotas išcentrinès jègos dydis.

Remiantis pateiktomis (6) ir (7) formulemis gali būti vertinamas pasipriešinimo jègos dydžio pasikeitimas. Daugiakanalio ciklono kanaluose dujų srauto Reinoldso skaičius yra didesnis nei 2300 , todèl srautas yra turbulentinio pobūdžio. Todèl taikant (7) formulę yra vertinamas apskaičiuotos pasipriešinimo jègos pokytis skirtingais agresyvios aplinkos atvejais. Laikoma, kad dalelè yra apvali, dalelès skersmuo $20 \mu \mathrm{m}$, o vidutinis dujų srauto greitis ciklone $-12 \mathrm{~m} / \mathrm{s}$. Apskaičiuoti rezultatai pateikti 3 pav. 


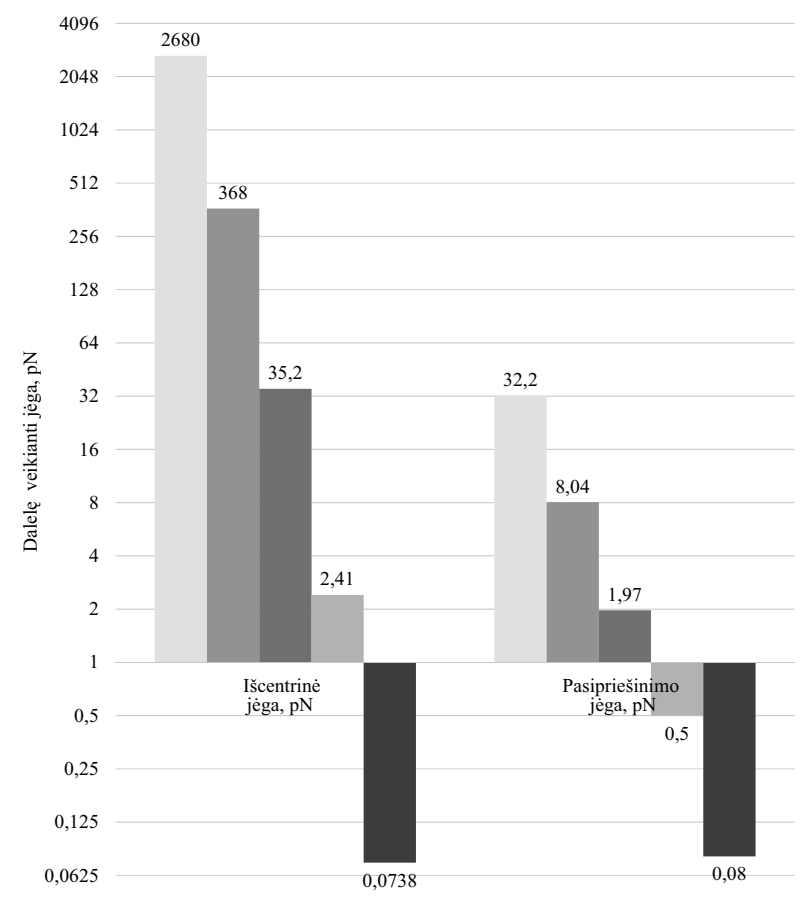

3 pav. Dalelę veikiančiu pasipriešinimo ir išcentrinès jègos pokytis logaritmineje skaleje, esant skirtingai agresyviai aplinkai

Fig. 3. Particle active resistance and centrifugal force variation-expected logarithmic scale at different aggressive environments

Dalelę veikianti išcentrinè jèga esant normalioms sąlygoms yra 83,2 karto didesnè nei pasipriešinimo. Tai galima sieti su daugiakanalio ciklono veikimo principo ypatumu, t. y. dalelių nusodinimu, kai jos, veikiamos sūkurinio judèjimo, yra išnešamos ị periferiją ir dèl svorio jègų nusodinamos ciklono apatinèje dalyje - bunkeryje. Tačiau, nagrinèjant skirtingus agresyvios aplinkos atvejus, galima matyti, kad kylant temperatūrai skirtumas tarp šių jègų mažèja, esant $50{ }^{\circ} \mathrm{C}$ temperatūrai $-45,77$ karto. Tendencija pastebima ir toliau, esant $100{ }^{\circ} \mathrm{C}$ ir $150{ }^{\circ} \mathrm{C}-$ skirtumas yra 17,87 ir 4,79 karto atitinkamai. Vertinant jègų skirtumą esant didžiausiai iš pasirinktų temperatūrų $200{ }^{\circ} \mathrm{C}$, pasipriešinimo jèga lygi $0,08 \mathrm{pN}$, o išcentrinè $0,074 \mathrm{pN}$. Todèl galima teigti, kad aplinkos sąlygos turi didelę ịtaką šioms jègoms, o esant aukštoms temperatūros šios jègos tampa apylygès.

Vertinant adhezijos jègą, pagal (9) formulę buvo apskaičiuotas didžiausias šios jëgos dydis, t. y. kai tarpas tarp dalelès ir plokštumos paviršiaus yra lygus $4 \cdot 10^{-10} \mathrm{~m}$. Gauti gravitacijos ir adhezijos jègų skaičiavimo rezultatai pateikti 4 pav.

Kaip galima matyti 3 pav., skirtumas tarp 1-20 $\mu \mathrm{m}$ dydžio daleles veikiančių jègų yra reikšmingas, ir jègų dydis didèja proporcingai dalelių dydžiui.

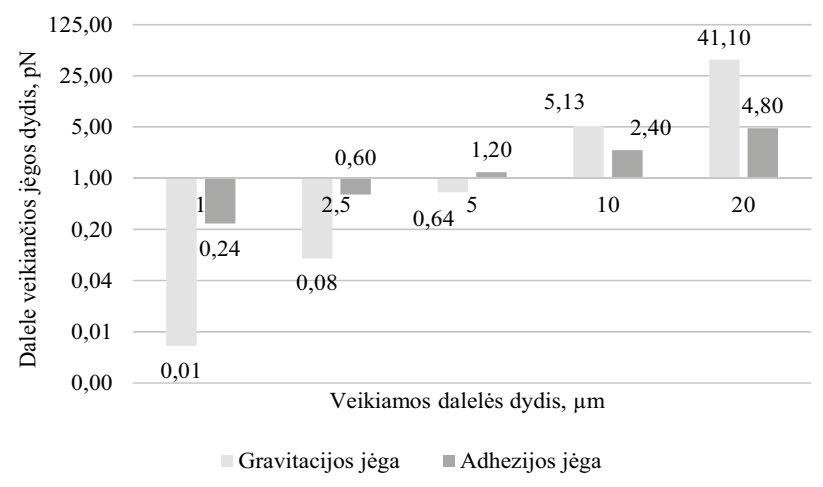

4 pav. Skirtingo dydžio daleles veikiančių gravitacijos ir adhezijos jëgos pokytis, esant skirtingoms agresyvios aplinkos sąlygoms

Fig. 4. Particles of different sizes operating in gravity and adhesion strength variation at different aggressive environments

Mažiausią iš pasirinktujų $1 \mu \mathrm{m}$ dydžio dalelę veikia $0,01 \mathrm{pN}$ dydžio gravitacijos jèga, o adhezijos jèga yra 24 kartus didesnè. Vertinant daleles, kurių dydis 2,5 ir $5 \mu \mathrm{m}$, skirtumas tarp šių jègu mažèja ir lygus 7,5 ir 1,88 karto atitinkamai.

Svarbu paminèti reikšmingą pokytị tarp šių jègų esant $10 \mu \mathrm{m}$ ir $20 \mu \mathrm{m}$ dydžio dalelèms. Šias daleles veikia stipresnès gravitacijos negu adhezijos jègos. Skirtumas tarp jègų esant $10 \mu \mathrm{m}$ dalelei yra 2,14 , o esant $20 \mu \mathrm{m}-8,56$ karto. Atsižvelgiant ị tai, galima prieiti prie išvados, kad dalelès, kurių dydis mažiau nei $5 \mu \mathrm{m}$, yra labiau linkusios kauptis ant daugiakanalio ciklono vidiniu elementu, nes adhezijos jẻga visiškai persveria gravitacijos jègą. Ir atvirkščiai, didesnès nei $5 \mu \mathrm{m}$ dalelès bus lengvai atitraukiamos nuo paviršiu net veikiant tik gravitacijos jègoms. Gravitacijos ir adhezijos jègos vertinamos tarpusavyje, kad būtų palygintas jų dydis, nes be daugiakanaliame ciklone daleles veikia ir kitos pagal dydị reikšmingos jègos.

Adhezijos, autohezijos bei kitų mechaninių jègų pokyčiai yra svarbūs vertinant daugiakanalio ciklono darbą esant agresyvioms sąlygoms. Ypač tokiomis sąlygomis, kai yra aukštas drègnis ir temperatūra. Tuo atveju kietosios dalelès susikaupia ciklone ir užkemša sistemą, dẻl ko toliau dujų srauto valyti negalima. Tai vertinant, būtina taikyti konstruktyvius sprendimus, ypač norint nukreipti smulkiąsias daleles nuo pagrindinių kaupimosi zonų, išvengti jų adhezijos su vidiniais paviršiais, prailginti ciklono veikimo trukmę esant agresyvioms aplinkos sąlygoms.

Vertinant fizikinius dujų srauto parametrus, esant skirtingoms agresyvioms aplinkos sąlygoms, buvo pastebèti reikšmingi pokyčiai $50-200{ }^{\circ} \mathrm{C}$ temperatūros intervale drègmès ịsotintoje aplinkoje. Didžiausi pokyčiai pastebèti esant $150^{\circ} \mathrm{C}$ ir $200^{\circ} \mathrm{C}$ temperatūroms, vertinant dujų srauto 
tankio ir klampos parametrus. Ivvertinus dalelę veikiančių jègų pokyčius pastebèta, kad agresyvios sąlygos daro didelę itaką visoms dalelę veikiančioms jègoms, o ypač - pasipriešinimo ir išcentrinei. Stipriausia iš nagrinètų dalelę veikiančių jègų gali būti laikoma slègio jèga.

\section{Išvados}

1. Agresyvios aplinkos sąlygos - aukšta temperatūra vandens garų prisotintame sraute - turi reikšmingą itaką dujų charakteristikoms. Sauso dujų srauto tankis ir kinematinès klampos koeficientas proporcingai mažèja, o drègno dujų srauto tankis ir dinaminès klampos koeficientas didèja. Esant $200{ }^{\circ} \mathrm{C}$ temperatūros ir $70 \%$ drègnio aplinkai, drėgno dujų srauto tankis padidèja 4,5 karto, o kinematinès klampos koefiecientas - 3,1 karto, lyginant su normaliomis sąlygomis.

2. Ivertinus daugiakanaliame ciklone veikiančias jègas i esančias dujų sraute daleles, nustatyta, kad viena iš didžiausių yra slègio jèga. Esant normalioms sąlygoms ši jèga lygi $1,07 \mathrm{mN}$, o esant $200{ }^{\circ} \mathrm{C}$ temperatūrai ir $70 \%$ drègniui, šis dydis padidèja apytiksliai $55 \%$, ir lygus 2,37 mN. Didžiausias pokytis pastebètas esant $150{ }^{\circ} \mathrm{C}$ ir didesnès temperatūros bei $70-80 \%$ drègnio agresyviai aplinkai.

3. Apvalios formos dalele, judèdama daugiakanaliame ciklone, kai vidutinis srauto greitis yra lygus $12 \mathrm{~m} / \mathrm{s}$, normaliomis sąlygomis yra veikiama $2,68 \mathrm{nN}$ išcentrine jèga ir 83,2 kartus mažesne - 32,2 pN pasipriešinimo jèga. Didejjant aplinkos agresyvumui, šios jègos reikšmingai mažèja, be to, mažèja ir skirtumas tarp jų dydžių verčių.

4. Daugiakanalio ciklono sistema užsikemša kietosiomis dalelèmis daugiausia dèl adhezijos jègų, o kietosios dalelès nusėda dèl gravitacijos jègos. Kai smulkiụjų dalelių skersmuo mažesnis nei $5 \mu \mathrm{m}$, jas veikia didesnè adhezijos negu gravitacijos jèga. Skirtumas tarp jëgų esant 1 ir $2 \mu \mathrm{m}$ dalelèms yra 24 ir 7,5 karto, o 5 ir $10 \mu \mathrm{m}$ dydžio daleles veikia jègos, tarp kurių skirtumas lygus 1,8-2,1 karto. Didžiausia 41,1 pN gravitacijos jèga yra veikiamos $20 \mu \mathrm{m}$ dalelès, tuo atveju apskaičiuota adhezijos jèga sudaro tik 11,68 \% nuo gravitacijos jègos ir lygi 4,8 pN.

\section{Literatūra}

Altmeyer, S.; Mathieu, V.; Jullemier, S.; Contal, P.; Midoux, N.; Rode, S.; Leclerec, J.-P. 2004. Comparison of different models of cyclone prediction performance for various operating conditions using a general software, Chemical Engineering and Processing 43: 511-522. http://dx.doi.org/10.1016/S0255-2701(03)00079-5
Avci, A.; Karagoz, I. 2003. Effect of flow and geometrical parameters on the collection efficiency in cyclone separators. Journal of Aerosol Science 34: 937-955. http://dx.doi.org/10.1016/S0021-8502(03)00054-5

Baltrènas, P.; Vaitiekūnas, P.; Jakštoniene, I.; Konoverskyte, S. 2012. Study of gas-solid flow in a multichannel cyclone, Journal of Environmental Engineering and Landscape Management 20(2): 129-137. http://dx.doi.org/10.3846/16486897.2011.645825

Bernardo, S.; Mori, M.; Peres, A.P.; Dionisio, R.P. 2006. 3-D computational fluid dynamics for gas and gas-particle flows in a cyclone with different inlet section angles, Powder Technology 162: 190-200. http://dx.doi.org/10.1016/j.powtec.2005.11.007

Burov, A. A.; Burov, I.; Gamolich, V. J. 2007. Continuum model curved dusty gas flow [Kontinual'naja model' zapylennogo krivolinejnogo techenija gaza], Work of Odessa Politechnical University 1(27): 235-237 (in Russian).

Europos Parlamento ir Tarybos direktyva 2008/50/EB. Dèl aplinkos oro kokybès ir švaresnio oro Europoje, Europos sajungos oficialusis leidinys L152: 1-44.

Gong, A. L.; Wang, L. Z. 2004. Numerical study of gas phase flow in cyclones with reeds, Aerosol Science and Technology 28: 506-512. http://dx.doi.org/10.1080/02786820490449548

Gordon, G. M.; Peisahov, I. L. 1977. Dust removal and purification of gases in non-ferrous metallurgy [Pyleulavlivanie $\mathrm{i}$ ochistka gazov v cvetnoj metallurgii], Moscow: Metallurgija. 455 p (in Russian).

Gujun, W.; Guogang, S.; Xiaohu, X.; Mingxian, S. 2008. Solids concentration simulation of different size particles in a cyclone separator, Powder Technology 183: 94-104. http://dx.doi.org/10.1016/j.powtec.2007.11.019

Hoffmann, A. C.; Stein, L. E. 2002. Gas cyclones and swirl tubes. Principles, design and operation. Berlin: Springer-Verlag. http://dx.doi.org/10.1007/978-3-662-07377-3

Hu, L. Y.; Zhou, L. X.; Zhang, J.; Shi, M. X. 2005. Studies on strongly swirling flows in the full space of volute cyclone separator, AIChE Journal 51(3): 740-749. http://dx.doi.org/10.1002/aic.10354

Yoshida, H.; Fukui, O.; Fukui, K. 2005. The effect of a new method of fluid flow control on submicron particle classification in gas-cyclones, Powder Technology 149: 139-147. http://dx.doi.org/10.1016/j.powtec.2004.10.005

Kaya, F.; Karagoz, I. 2008. Performance analysis of numerical schemes in highly swirling turbulent flows in cyclones, Current Science 94(10): 1273-1278.

Luca, F. A.; Ioan, C. A. M. 2012. Air quality management in Iasi city, Environmental Engineering and Management Journal 11(2): 377-383.

Mothes, H.; Loffler, F. 1988. Prediction of particle removal in cyclone separators, International Chemical Engineering 28: $51-55$.

Pushnov, A; Berengarten, M. 2011. Ecological aspects of industrial cooling towers exploitation and it's influence to environment, Journal of Environmental Engineering and Landscape Management 19(2): 158-166. http://dx.doi.org/10.3846/16486897.2011.583390

Raoufi, A.; Shams, M.; Kanani, H. 2008. CFD analysis of flow field in square cyclones, Powder Technology 1-9. 
Sobolev, A. A.; Melnikov, P. A.; Tyutyunik, A. O. 2011. Particle movement into the air stream [Dvizhenie chastic v vozdushnom potoke], Masinostroenie, Vektor Nauki TGU 3(17): $82-86$ (in Russian).

Tarybos direktyva 1999/30/EB. Dèl sieros dioksido, azoto dioksido, azoto oksidų, kietujų dalelių ir švino ribinių verčių aplinkos ore, Europos sajungos oficialusis leidinys 15(4): 164-183.

Vaitiekūnas, P.; Jakštonienė, I. 2010. Analysis of numerical modeling of turbulence in a conical reverse-flow cyclone, Journal of Environmental Engineering and Landscape Management 18(4): 321-328. http://dx.doi.org/10.3846/jeelm.2010.37

Wang, B.; Xu, D. L.; Chu, K. W.; Yu, A. B. 2006. Numerical study of gas-solid flow in a cyclone separator, Applied Mathematical Modelling 30: 1326-1342. http://dx.doi.org/10.1016/j.apm.2006.03.011

Winfield, D.; Cross, M.; Croft, N.; Paddison, D.; Craig, I. 2013. Performance comparsion of a singand triple tangential inlet gas separation cyclone: a CFD study, Powder Technology 235: $520-531$.

http://dx.doi.org/10.1016/j.powtec.2012.10.026

Zhao, B.; Su, Y.; Zhang, J. 2006. Simulation of gas flow pattern and separation efficiency in cyclone with conventional single and spiral double inlet configuration, Trans IChemE. PA, Chemical Engineering Research and Design 84: 1158-1165. http://dx.doi.org/10.1205/cherd06040

\section{THEORETICAL VALUATION OF MULTI-CHANNEL CYCLONE TO REDUCE GAS FLOW DUSTINESS IN AGGRESSIVE ENVIRONMENT}

\section{A. Chlebnikovas, P. Baltrènas}

Abstract

Contaminated gas cleaning from finely divided solids is carried out using a new generation of multi-channel design cyclones. The application of these devices are separated and precipitated particles with a minimum diameter up to 2 micrometers, reaching up to $95 \%$ cleaning efficiency. Cyclones of such constructions are usually used under usual conditions at elevated temperature and low humidity. Under aggressive conditions, these devices can be clogged, and their recovery is not possible. Further studies are research into the application of constructive solutions to adapt the cyclone gas cleaning of the particulate matter under aggressive conditions. This theoretical evaluation has described the characteristics change of gas flow and particulate matters at different aggressive environment. Such conditions were loudly describe the gas-flow high-temperature range of $50-200{ }^{\circ} \mathrm{C}$ and gas-vapor stream, the humidity reaches $70-100 \%$. Estimated aggressive conditions on the gas flow dynamics forces - pressure, resistance and centrifugal, and particulate mechanical - gravitational and adhesion strength. All parameters are evaluated in comparison with the values under normal conditions.

Keywords: multi-channel cyclone, aggressive environment, particulate matter. 